\title{
Effects of Contract Strategy on Interpersonal Relations and Project Outcomes of Public-Sector Construction Contracts in Australia
}

\author{
Yongjian Ke, Florence Y. Y. Ling, and Patrick X. W. Zou
}

\begin{abstract}
Hitherto, it is not known if the integration of relationship concepts into traditional publicsector construction contracts would improve project performance. This study hence examines the effects of contract strategies on project outcomes and relationship quality in the context of publicsector construction projects in Sydney, Australia. It also identifies the relational contracting (RC) practices that are in place when certain contract strategies are adopted. Using a two-pronged research design, data were first collected from public owners and private contractors and consultants through a questionnaire survey. The data were analysed and the results were then validated by interviews. Correlation analysis shows that cost performance, client satisfaction, and relationship quality among contracting parties are significantly correlated with contract strategies. The findings indicate the important role that contract strategies play in project outcomes and interpersonal relationship. Among the 20 RC practices that are significantly correlated with contract strategies, 16 of them are related to clients and consultants, suggesting their important role in setting the tone of the relationship in a project.
\end{abstract}

Keywords: Relational contracting; Public construction projects; Relationship; Strategy; Sydney, Australia

\section{Introduction}

An appropriate contracting method coupled with clear and equitable contract documents do not ensure project success because the attitudes of the contracting parties and the relationships among the project participants are also equally important (Rahman and Kumaraswamy 2002a). The use of collaborative transactions may reduce disputes and increase team harmony, leading to better project performance (Walker 1998; Schwenk and Cosier 1993). On the other hand, relationship conflicts arising from interpersonal problems, friction, and personality clashes cause group members to work less effectively and produce suboptimal products (Argyris 1962). Rahman and Kumaraswamy (2002a) found that collaborative transaction through the adoption of relational contracting (RC) practices may be useful in reducing transaction costs as well as fostering cooperative relationships and better teamwork.

Copyright: Journal of Management in Engineering 2015. (C) 2016 Yongjian Ke, Florence Y. Y. Ling, and Patrick X. W. Zou. This is an Open Access article distributed under the terms of the Creative Commons Attribution 4.0 Unported (CC BY 4.0) License (https://creativecommons.org/licenses/by/4.0/), allowing third parties to copy and redistribute the material in any medium or format and to remix, transform, and build upon the material for any purpose, even commercially, provided the original work is properly cited and states its license.

Citation: Ke, Y., Ling, F. Y. Y., \& Zou, P. X. W. (2015). Effects of contract strategy on interpersonal relations and project outcomes of public-sector construction contracts in Australia. Journal of Management in Engineering, 31(4), 04014062. doi: 10.1061/(ASCE)ME.19435479.0000273

Corresponding author: Yongjian Ke; Email - Yongjian.Ke@uts.edu.au 
In Australia, alliance contracting as a relationship-based contractual arrangement is being used by public-sector clients to obtain value for money (Davis et al. 2009). This is a new alternative to traditional project-delivery systems to reduce the adversarial nature of most construction projects. In July 2011, the Infrastructure Working Group of the Council of Australian Governments issued the National Alliance Contracting Policy and Guidelines to provide a consistent national standard and promote practices for relational delivery (Dept. of Infrastructure and Transport 2013). However, there are many disputes on whether alliances have delivered value for money in past projects (Dept. of Treasury and Finance 2009). Hitherto, it is not known if the integration of relationship concepts into traditional public-sector construction contracts would improve project performance.

The aim of this study is hence to investigate whether contract strategies affect project outcomes and interpersonal relations among contracting parties in public construction projects in Sydney, Australia. The specific objectives are to (1) investigate the contract strategies adopted in public projects, (2) find out if the type of contract strategies that are significantly correlated with project outcomes and interpersonal relations among contracting parties, and (3) discover the types of RC practices that must be in place when certain contract strategies are adopted. Because Australia covers a large area, the scope of this study is confined to public construction projects in Sydney. The contract strategies are confined to those affecting relationships, as defined in the next section.

\section{Literature Review}

\subsection{Project Outcomes}

Project outcomes include the traditional triple project outcomes (completion within budget, on time, and to an acceptable level of quality), safety performance, environmental performance, stakeholder satisfaction, and profitability. This study considered project performance from the view of project delivery and organizational level competency. Under project delivery, the three main triple project outcomes, cost (Y1), time (Y2), and quality (Y3), were adopted as the performance metrics following Konchar and Sanvido (1998). For organizational-level competency, service quality was operationalized as client satisfaction with the project (Y4) following Ling et al. (2004).

However, the previously mentioned performance metrics tell the contracting parties little or nothing about the condition of the environment in which the performance is attained (Crane et al. 1999). Crane et al. (1999) adopted relationship measures to track the activities and effectiveness of the working team. Cheung et al. (2003) also argued that it is necessary to use relationship measures to assess the behavioural aspects. The strength of relationships, including harmony during project implementation (Z1) and relationships between client and contractor (Z2), between contractor and consultant (Z3), and between client and consultant (Z4) at the end of project were used in this study.

\subsection{Contract Strategies Affecting Relationships}

Based on the theory of the firm (Coase 1937), companies in the construction industry would attempt to maximize their economic profit. They participate in public construction projects with the intention of increasing their revenue. They usually prefer to adopt formal contracts, which contain fairly explicit stipulations of proscribed and prescribed behaviours and risk allocation. This choice of organizational strategy is governed by the rational choice theory (Becker 1976). According to this theory, companies pursue their interests rationally, try to maximize utility, and would resort to institutional arrangements and formal contracts to guard against troubles, ignoring the identity of and past relationships with individual actors (Becker 1976). 
The basic idea behind the rational choice theory is that individuals make choices that can best help them achieve their objectives (Green and Shapiro 1996). Once the behaviour of one individual is established, this is assumed to be typical or representative of some larger group of actors in a particular market (Becker 1976). When decisions are made using the rational-choice approach, these decision makers are termed as economic men who exhibit self-interested behaviour (Williamson 1975). These economic men rely on institutional arrangements to guard against trouble, transact with others based on pure economic motives, ignoring the identity of and any past relationships with the individual actor.

However, risk is inherent and difficult to deal with in a construction project. It is difficult for the partners to completely predict potential problems and outcomes and have all essential information. The basic assumptions of expected utility maximization under conditions of uncertainty are especially problematic (Machina 1987).

The converse of rational choice is not irrational choice, but relational choice. Decision makers rationally and deliberately make relational choices if these lead to profit in the long run, when longterm and future relationships are involved (Eccles 1981). Relational choices exist because most behaviours are closely embedded in networks of social relations (Granovetter 1985). The decision maker may look beyond rational choice to consider not only economic goals but also sociability, approval, status, and power (Hirschman 1977). In other words, the objective of behaviours is therefore not only to maximize utility but also to take into account other social goals (Granovetter 1985).

Jones et al. (1997) proposed that four conditions promote embeddedness among parties: demand uncertainty with stable supply, complex tasks under time pressure, customized exchanges high in human asset specificity, and frequent exchanges among parties embedded in the network. These conditions exist in construction projects, which are generally characterized by high risks, complex tasks, tight schedules, and long project durations. It is understandable that participants in a construction project are usually closely embedded in a social network of relations. Pryke (2004) had conceptualized the construction project coalition as a network of relationships. Ling and Li (2012) found that network strategies are relevant to manage construction projects effectively.

The previous literature review suggests that the contract strategies that firms pursue may be solely economic profit (rational choice) or a balance of economic and social goals (relational contracting). This would determine the following: basis upon which choices and decisions are made, ranging from rational choice to relational choice (X1); focus of the firm, ranging from mostly profit to mostly relationship (X2); and way of guarding against trouble, ranging from relying on formal contractual controls to trust (X3).

\subsection{Relational Contracting}

$\mathrm{RC}$ is based on the recognition of mutual benefits and win-win scenarios through more cooperative relationships among contracting parties (Rahman and Kumaraswamy 2004a). It underpins various approaches, such as partnering, alliancing, joint venturing, long term contracting, joint risk-sharing mechanisms, integrated project delivery, and other collaborative working arrangements (Rahman and Kumaraswamy 2004a; American Institute of Architects 2007).

The literature on RC practices were reviewed and summarized in Table 1. In this paper, the term RC practices is taken to mean relational practices, or practices based on good relationship management, 
which are RC type or RC based, even though the actual contracts may not have formal RC approaches incorporated into them.

Table 1. Relational Contracting Features and Practices Identified in Current Literature

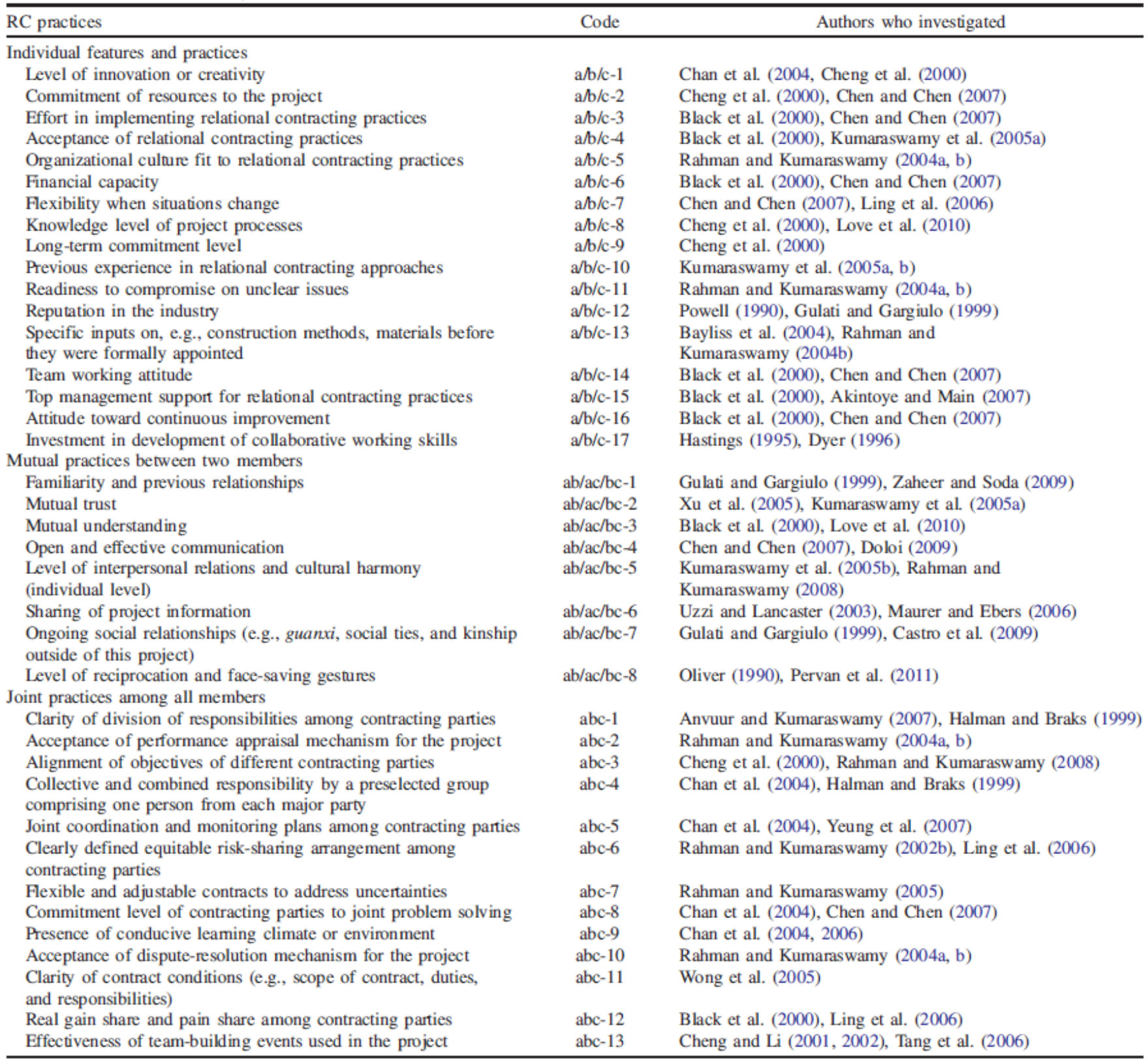

Note: a, b, and c in code column refers to client, contractor, and consultant, respectively.

RC practices are divided into three categories: individual organizational features and practices adopted by each contracting party, practices adopted in tandem by two of the contracting parties, and practices adopted by all the major contracting parties in unison (Table 1). For brevity, these practices are coded as a, b, and c for client, contractor, and consultant, respectively, followed by a reference number. Individual organizational features and practices adopted by each contracting party are coded as a-\#, b-\#, and c-\#; practices adopted in tandem by two of the contracting parties are coded as ab-\#, ac-\#, and bc-\#; and practices adopted by all the major contracting parties in unison are coded as abc\#. The number symbol represents the reference number of the RC practice. 


\subsection{Knowledge Gap}

The brief literature review suggests that there are different contract strategies affecting relationships (X1, X2, and X3). The gap in knowledge is that it is not known if the adoption of a certain contract strategy could lead to good outcomes in public construction projects. Another gap in knowledge is that it is not known what RC practices are associated with a contract strategy. The fieldwork was thus undertaken to uncover the association between contract strategies and project outcomes, and between RC practices and contract strategies.

\section{Research Methodology}

\subsection{Research Design and Data Collection}

A two-pronged research design was adopted for this study, the first being a structured questionnaire survey conducted between June and November 2011 in Sydney, Australia. Respondents were requested to provide the data of a completed public-sector project in which they had been involved. The objectives of the survey were to evaluate the strength of relationships among contracting parties, the performance outcomes of completed public construction projects, the contract strategies adopted, and the extent to which the RC practices were present, observed, practiced, or emphasized in the project.

The questionnaire comprised several sections. Section A requested information on the completed public-sector project, the strength of the relationships among contracting parties, the contract strategies adopted, and the project's performance outcomes. The strength of relationships, including harmony during project implementation (Z1) and relationships between client and contractor (Z2), between contractor and consultant (Z3), and between client and consultant (Z4) at the end of project were rated by a five-point Likert scale $(1=$ very low, $3=$ neutral, $5=$ very high $)$. Respondents were requested to provide the cost (Y1) and time (Y2) performance based on planned and actual numbers. Quality performance (Y3) and client satisfaction (Y4) were rated on a five-point Likert scale (1 = very dissatisfied, 3 = neutral, 5 = very satisfied).

The contract strategies adopted were measured using three dimensions: $\mathrm{X} 1$ = basis for decision making; X2 = organizational focus in the project; and X3 = method to guard against trouble. These were measured on a five-point Likert scale. For X1, the anchors were 1 = rational choices mostly, 3 $=$ both rational and relational choices equally, and 5 = relational choices mostly. For X2, the anchors were 1 = profit and cost mostly, $3=$ both profit and cost and relationship equally, and $5=$ relationship mostly. For X3, the anchors were $1=$ contract mostly, $3=$ both contract and network equally, and $5=$ network mostly. In Section B, respondents were asked to indicate the extent to which RC practices were adopted on a five-point Likert scale $(1=$ very low, $3=$ neutral, $5=$ very high). Respondents were also given the opportunity to provide other suggestions and comments as well as demographic characteristics of themselves and their companies.

The unit of analysis is a completed public-sector project, regardless of the extent to which RC approaches were adopted. The population is thus completed public projects in Australia and the sampling frame is completed public projects in Sydney, Australia. To collect the data, multiple stakeholders comprising public-sector clients and consultants, private-sector consultants (e.g., architects, engineers, quantity surveyors, and project managers), and contractors who had been involved in public construction projects in Sydney were approached. The sampling frame for public officials was obtained from government directories, and questionnaires were sent to all of them because the sample size is not large. The sampling frames for private consultants and contractors 
were derived from the respective professional and trade institutions; samples were selected randomly. Because this group may contain those who have not handled public projects before, the questionnaire clearly stated that only those who had completed public projects should fill out the questionnaire.

The next step to validate the statistical results and elaborate on the findings of the questionnaire survey was done by conducting in-depth interviews with practitioners and academics in Australia. They were identified through convenience sampling. A content analysis of the interview transcripts was conducted to distil the findings.

\subsection{Data Analysis Method}

The data were analysed using SPSS software. The main statistical methods used were descriptive statistics, one-sample t-test, and Pearson's correlation analysis. The confidence interval (CI) was set at 0.95 . The one-sample t-test procedure was performed on the contract strategies (X1 to X3), the performance metrics ( $\mathrm{Y} 1$ to Y4), and the relationship metrics (Z1 to Z4) to determine if the RC strategy was adopted to a significant extent and if the projects had significantly good performance and relationships. The test value to be compared for X1 to X3, Y1 to Y4, Z3, and Z4 was 3 (neutral), while the test value for $\mathrm{Z} 1$ and $\mathrm{Z} 2$ was 0 (actual cost and time equal to planned cost and time). To determine whether a greater adoption of the RC strategy led to better project outcomes, Pearson's correlation analysis was conducted. Each pair of variables in the Pearson's correlation analysis comprised one of the three dimensions of contract strategies (X1 to X3) and one of the four performance metrics (Y1 to Y4) or one of the four relationship metrics (Z1 to Z4). Another round of Pearson's correlation analysis was conducted to discover the types of RC practices (Table 1) that were in place when certain contract strategies (X1 to X3) are adopted. Each pair of variables in this round of Pearson's correlation analysis comprised one of the three dimensions of contract strategies (X1 to X3) and one of the RC practices (Table 1).

\section{Characteristics of the Sample}

Survey questionnaires were sent to 322 target respondents in Sydney, Australia. A total of 30 valid completed questionnaires were returned, with one respondent who did not provide personal data. The response rate of $9.3 \%$ is relatively low and the sample size of 30 is small. However, statistical analysis could still be performed because in accordance with the generally accepted rule, the central limit theorem holds true when the sample size is no less than 30 (Ott and Longnecker 2001).

To ensure the same project is not captured more than once, when the data were received the project information including planned and actual numbers of cost and time performance, type of client, contractual arrangement, bidding method for contractors, and consultants were checked. No responses from the same project were received. The characteristics of the respondents are given in Table 2.

The respondents' experience in various types of public construction projects, which covered predominantly public housing, infrastructure (transportation, water plant, and power plant), and other buildings (offices, hospitals, and schools). The number of years of respondents' experience ranged from 2 to 45 years, with an average of 24 years. Seventy-two percent of the respondents had no less than 15 years of experience. The respondents' firms engaged between 3 and 100,000 employees, with an average of 7,037 employees. The results showed that $67.9 \%$ of the respondents' firms had more than 200 employees. 
Table 2. Characteristics of Respondents and Their Projects

\begin{tabular}{|c|c|c|}
\hline Characteristics & Number & Percentage \\
\hline \multicolumn{3}{|l|}{ Experience in construction industry } \\
\hline$<5$ years & 6 & 21 \\
\hline $5-9$ years & 1 & 3 \\
\hline $10-14$ years & 1 & 3 \\
\hline$\geq 15$ years & 21 & 72 \\
\hline Average & \multicolumn{2}{|c|}{24} \\
\hline Minimum & \multicolumn{2}{|c|}{2} \\
\hline Maximum & \multicolumn{2}{|c|}{45} \\
\hline \multicolumn{3}{|l|}{ Organization type } \\
\hline Government & 9 & 31 \\
\hline Engineering firm & 2 & 7 \\
\hline Architectural firm & 1 & 3 \\
\hline Quantity surveying firm & 1 & 3 \\
\hline Contractor & 16 & 55 \\
\hline \multicolumn{3}{|l|}{ Ownership of organization } \\
\hline Public & 16 & 55 \\
\hline Private & 13 & 45 \\
\hline \multicolumn{3}{|l|}{ Size of total workforce } \\
\hline 1-20 employees & 2 & 7 \\
\hline 21-200 employees & 7 & 25 \\
\hline$>200$ employees & 19 & 68 \\
\hline Average & \multicolumn{2}{|c|}{7,037} \\
\hline Minimum & \multicolumn{2}{|c|}{3} \\
\hline Maximum & \multicolumn{2}{|c|}{100,000} \\
\hline \multicolumn{3}{|l|}{ Type of facility } \\
\hline Residential & 6 & 20 \\
\hline Infrastructure & 7 & 23 \\
\hline Other buildings & 17 & 57 \\
\hline \multicolumn{3}{|l|}{ Type of client } \\
\hline One-off client & 3 & 10 \\
\hline On-off client & 6 & 20 \\
\hline Ongoing client & 21 & 70 \\
\hline \multicolumn{3}{|l|}{ Contractual arrangement } \\
\hline Design-bid-build with bills of quantities & 14 & 46 \\
\hline Design-bid-build based on lump sum & 9 & 30 \\
\hline Design and build & 7 & 23 \\
\hline \multicolumn{3}{|l|}{ Bidding method for selection of contractor } \\
\hline Open competitive bidding & 6 & 20 \\
\hline Selective bidding & 17 & 57 \\
\hline Negotiation & 7 & 23 \\
\hline \multicolumn{3}{|l|}{ Bidding method for selection of consultant } \\
\hline Open competitive bidding & 4 & 13 \\
\hline Selective bidding & 13 & 43 \\
\hline Negotiation & 10 & 34 \\
\hline In-house consultant & 3 & 10 \\
\hline
\end{tabular}

Note: When $n \neq 30$, this is due to missing data.

According to Table 2, the majority (70\%) of the clients are on-going clients. This indicates that the findings would be more applicable to clients with the knowledge and experience in project management who would be able to add value to construction projects. Table 2 also reinforces the notion that government procurement for construction and engineering services are generally transparent. Selective bidding, in which an invitation to tender is made to a limited number of tenderers, is the most frequently used method in selecting contractors and consultants. The results also show that government in-house consultants (10\%) play some part in providing architectural and engineering professional services. 
Table 3 shows that projects had significantly harmonious relationships during project implementation $(\mathrm{Z1}$ : mean $=3.50, \mathrm{p}=0.045)$, pointing to good ongoing relationships. At the end of the project, there were also significantly good relationships between clients and contractors ( $\mathrm{Z} 2$ : mean $=3.93, p=0.000)$, between contractors and consultants $(Z 3$ : mean $=3.76, p=0.002)$, and between clients and consultants $(\mathrm{Z} 4$ : mean $=3.70, \mathrm{p}=0.002)$.

The t-test results in Table 3 also show that public construction projects in Australia achieved significantly good quality performance $(Y 3$ : mean $=4.27, \mathrm{p}=0.000)$ and client satisfaction $(\mathrm{Y} 4$ : mean $=3.97, \mathrm{p}=0.000)$, but had significantly poor cost performance $(\mathrm{Y} 1: 11.73 \%$ cost overrun, $\mathrm{p}=$ $0.005)$ and time performance (Y2: 13.60\% schedule overrun, $\mathrm{p}=0.007)$.

In the second stage, eight subject matter experts in Australia were interviewed after much persuasion and many follow-up telephone calls. Their experience in the construction industry ranged from 4 to 25 years, with an average of 15.3 years. They work for the public client, contractors, and research institutes.

\section{Result 1: Contract Strategies and Their Effects}

\subsection{Contract Strategies}

The first objective of this study is to investigate the contract strategies that are adopted in public projects in Australia. The one sample t-test results in Table 3 show that contracting parties in public projects in Australia adopt balanced contract strategies that neither lean significantly towards rational choice nor significantly towards relational choice. The results indicate that they consider both rational and relational choices equally when making decisions (X1), focus on both profit and relationship (X2), and rely on both formal contract and trust to guard against troubles (X3). The findings agree with Cheung et al. (2006) that a contractual relationship is not absolutely relational or completely discrete, but exists on a spectrum, which ranges from relational to discrete.

A closer look at the contract strategies on relationships was taken in Fig. 1. The majority of the contracting parties considered both profit and cost and relationship as their focus in the public projects because the median, upper, and lower quartiles all fell in the 3-both profit and cost and relationship equally category. A slightly higher agreement was seen in making decisions based on rational choices than relational choices, as well as in guarding against trouble based on contractual arrangements than network and relationships because the lower quartiles were in the 2 category for basis for decision making and method to guard against trouble.

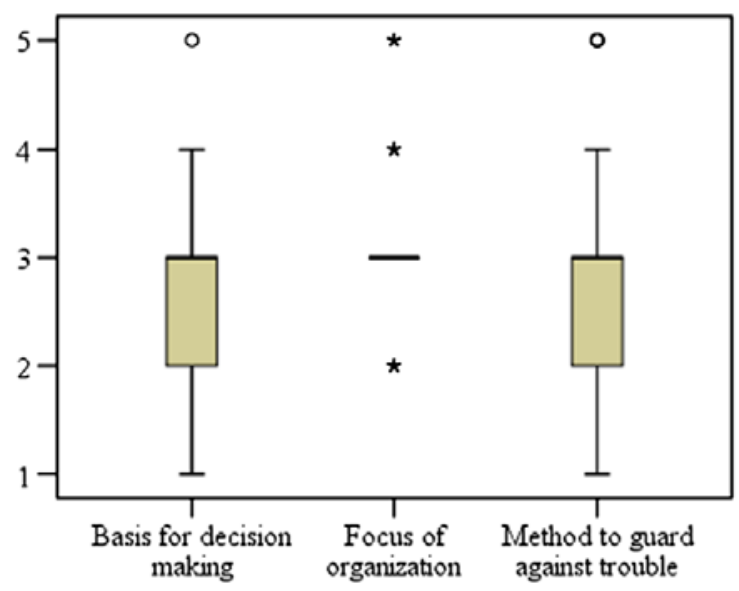

Fig. 1. Contract strategies in public projects 


\subsection{Effects of Contract Strategies}

The second objective of this study is to find out if contract strategies affect project outcomes and interpersonal relations among contracting parties. Correlation analysis was conducted to identify associations among contract strategies (X1 to X3), project outcomes (Y1 to Y4), and quality of relationships (Z1 to Z4). The results are shown in Tables 4 and 5, and the significant correlations are depicted in Fig. 2.

Table 4. Correlation Results of Contract Strategies and Project Outcomes

\begin{tabular}{lccc}
\hline & $\begin{array}{c}\text { Basis for } \\
\text { decision } \\
\text { making } \\
(\mathrm{X} 1)\end{array}$ & $\begin{array}{c}\text { Focus of } \\
\text { organization } \\
(\mathrm{X} 2)\end{array}$ & $\begin{array}{c}\text { Method to } \\
\text { guard against } \\
\text { trouble (X3) }\end{array}$ \\
Code & $\mathbf{0 . 4 5 8}$ & -0.032 & 0.009 \\
Cost performance (Y1) & 0.014 & 0.872 & 0.966 \\
Time performance (Y2) & -0.009 & -0.081 & -0.126 \\
& 0.965 & 0.676 & 0.523 \\
Quality performance (Y3) & -0.069 & -0.057 & -0.038 \\
& 0.718 & 0.764 & 0.847 \\
Client satisfaction (Y4) & 0.199 & 0.269 & $\mathbf{0 . 3 8 7}$ \\
& 0.291 & 0.151 & 0.038 \\
Harmony during project (Z1) & $\mathbf{0 . 4 3 4}$ & $\mathbf{0 . 4 1 7}$ & $\mathbf{0 . 6 0 9}$ \\
& 0.016 & 0.022 & 0.000 \\
Relationships between client & $\mathbf{0 . 4 2 4}$ & 0.255 & 0.332 \\
and contractor at the end (Z2) & 0.020 & 0.173 & 0.079 \\
Relationships between contractor & $\mathbf{0 . 4 5 5}$ & 0.251 & $\mathbf{0 . 3 7 6}$ \\
and consultant at the end (Z3) & 0.013 & 0.189 & 0.049 \\
Relationships between client & $\mathbf{0 . 3 7 4}$ & 0.331 & $\mathbf{0 . 5 6 0}$ \\
and consultant at the end (Z4) & 0.042 & 0.074 & 0.002 \\
\hline
\end{tabular}

Note: The values with bold are significant at the 0.05 level.

Table 5. Multiple Linear Regression Results

\begin{tabular}{|c|c|c|c|c|c|c|c|c|}
\hline $\begin{array}{l}\text { Dependent } \\
\text { variable }\end{array}$ & $R^{2}$ & Adjisted $R^{2}$ & $\begin{array}{c}\text { Independent } \\
\text { variable }\end{array}$ & $\beta$ & $\sigma$ & $b$ & $t$ value & $p$ value \\
\hline \multirow[t]{2}{*}{$\mathrm{Zl}$} & & & Constant & 1.316 & 0.578 & $\mathrm{NA}$ & 2.279 & 0.031 \\
\hline & 0.371 & 0.348 & X3 & 0.748 & 0.187 & 0.609 & 3.993 & 0.000 \\
\hline \multirow[t]{2}{*}{$\mathrm{Z} 2$} & & & Constant & 2.887 & 0.463 & NA & 6.239 & 0.000 \\
\hline & 0.193 & 0.163 & X1 & 0.406 & 0.160 & 0.439 & 2.540 & 0.017 \\
\hline \multirow[t]{2}{*}{$\mathrm{Z} 3$} & & & Constant & 2.472 & 0.531 & NA & 4.651 & 0.000 \\
\hline & 0.216 & 0.186 & X1 & 0.484 & 0.181 & 0.465 & 2.677 & 0.013 \\
\hline \multirow[t]{2}{*}{$\mathrm{Z} 4$} & & & Constant & 2.025 & 0.514 & NA & 3.937 & 0.001 \\
\hline & 0.314 & 0.289 & X3 & 0.586 & 0.167 & 0.560 & 3.517 & 0.002 \\
\hline \multirow[t]{3}{*}{ Y1 } & & & Constant & 1.972 & 0.601 & NA & 3.285 & 0.003 \\
\hline & 0.217 & 0.186 & X1 & -0.602 & 0.169 & -0.577 & -3.553 & 0.002 \\
\hline & 0.406 & 0.356 & X3 & 0.502 & 0.182 & 0.449 & 2.762 & 0.011 \\
\hline \multirow[t]{2}{*}{ Y4 } & & & Constant & 2.911 & 0.515 & NA & 5.649 & 0.000 \\
\hline & 0.149 & 0.118 & X3 & 0.364 & 0.167 & 0.387 & 2.178 & 0.038 \\
\hline
\end{tabular}

Note: NA = not applicable. 


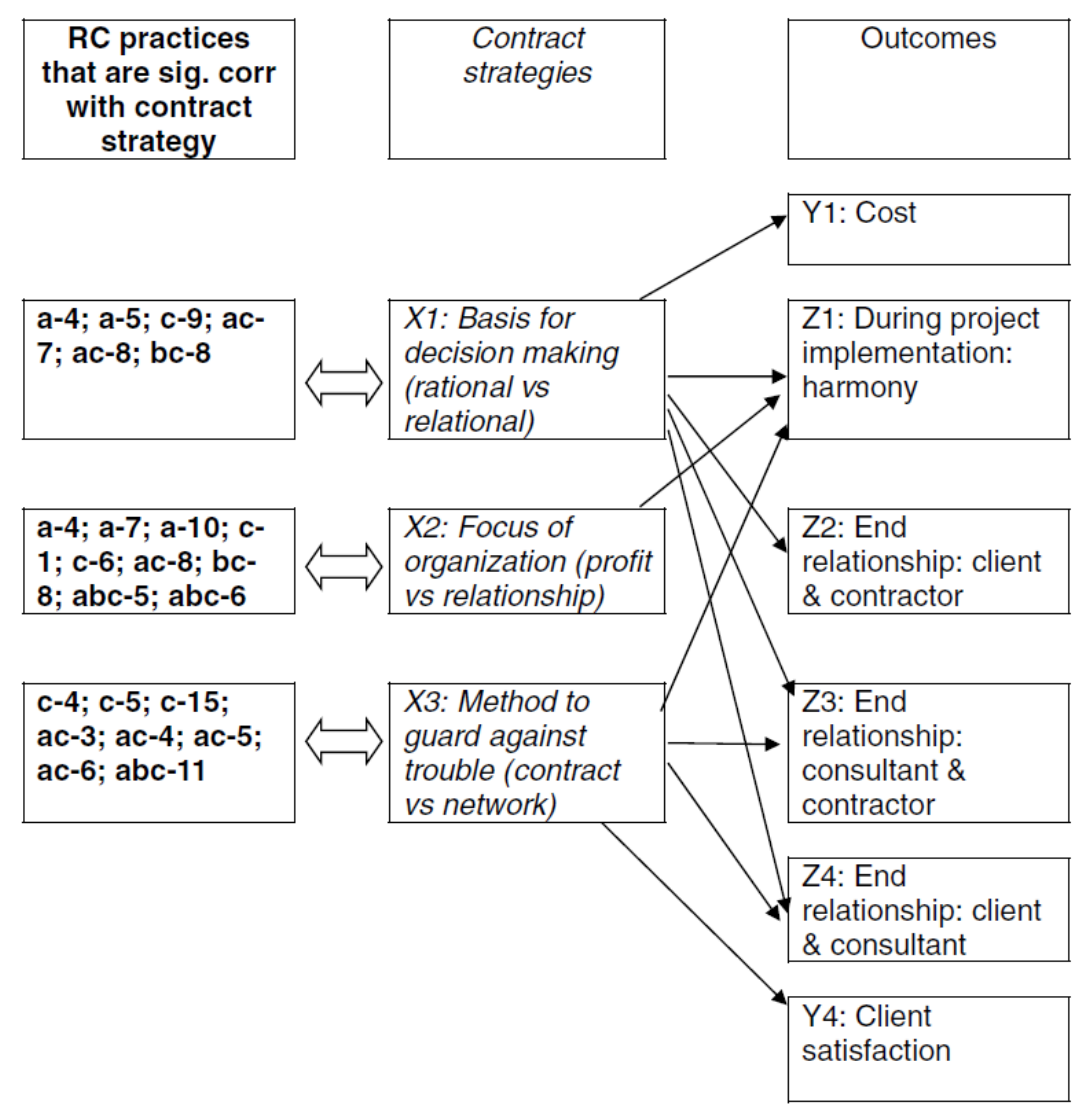

Legend: $\rightarrow$ Significant correlation between variables

Fig. 2. Associations between contract strategies and outcomes

There is significant correlation between the basis for decision making (X1) and the quality of relationships including harmony during project implementation (Z1) and relationships between client and contractor (Z2), between contractor and consultant (Z3), and between client and consultant (Z4) at the end of project (Table 4). Table 5 shows that X1 may be used to explain 16 and 19\% of the variability in Z2 and Z3, respectively. When parties make decisions or choices based on a relational contract as opposed to rational choices, relationships among them improve. This may be because relational approaches decrease the occurrence of conflicts, leading to improved task performance (Guzzo and Shea 1992). Relational approaches also allow members to collaborate to develop good designs (Kluenker 1996). These good outputs pull parties together to produce deep relationships.

Table 4 shows significant correlation between the basis for decision making (X1) and cost performance (Y1), and it accounts for 19\% variability in Y1 (Table 5). The result suggests that if choices or decisions are mostly relational, cost overrun will worsen. The expense of conducting RC practices has often been cited as a reason to avoid the process (Glagola and Sheedy 2002; Chan et al. 2003). It is because the formation of a relationship arrangement requires extra staff, time, and resources, which makes it possibly costly to align all parties (Larson and Drexler 1997).

Table 4 also shows a significant correlation between the focus of an organization (X2) and the level of harmony during project implementation (Z1). This finding suggests that when contracting parties focus more on relationships rather than profit and cost only, they have a higher level of harmony. The finding agrees with Rahman and Kumaraswamy (2008), who found that integrated objectives among contracting parties is a significant critical factor for facilitating RC. Contracting parties are generally adversaries who need to protect and enforce their individual rights, minimize their 
liabilities, and maximize their profits. Less emphasis on their own profit and cost would possibly change their adversarial positions and this leads to a higher level of harmony.

Table 4 shows a significant correlation between the method used to guard against trouble (X3) and the quality of relationships including harmony during project implementation (Z1), between contractor and consultant (Z3), and between client and consultant (Z4) at the end of project. Table 5 shows that X3 accounts for 35 and $29 \%$ of variability in $\mathrm{Z} 1$ and Z4, respectively. There is also a significant correlation between the method used to guard against trouble (X3) and client satisfaction (Y4), accounting for $12 \%$ of variability in Y4. Parties may guard against trouble by agreeing on a common dispute-resolution mechanism. This helps to improve relationships (Rahman and Kumaraswamy 2004a, b). When network and relationships are much relied on to handle trouble, contracting parties may be less adversarial and hence have better ongoing and end relationships. Clients are likely to be more satisfied as the level of client satisfaction could be determined by the transformation process (Yasamis et al. 2002). One of the interviewees explained that when disputes arose, sometimes renegotiation among partners, especially with the government, is more efficient and effective than institutional arrangement such as arbitration or a lawsuit because these cause significant delay and create bad relationships in the project.

\section{Result 2: Contract Strategies and Their Corresponding Practices}

The third objective of this study is to discover the types of practices that are in place when certain contract strategies are adopted. Correlation analysis was conducted between the RC practices adopted in Table 1 and the contract strategies implemented (X1 to X3). The results are shown in Table 6. There are 20 RC practices that are significantly correlated with the contract strategies, including four individual practices of clients, six individual practices of consultants, and six practices adopted in tandem by clients and consultants, suggesting that clients and consultants play an important role in setting the tone of the relationship in the project.

Table 6. Significant Correlation between Relational Contracting Practices and Contract Strategies

\begin{tabular}{|c|c|c|c|c|c|c|c|c|c|}
\hline \multirow[b]{2}{*}{ Code } & \multirow[b]{2}{*}{ Mean } & \multicolumn{2}{|c|}{$t$-test } & \multicolumn{2}{|c|}{$\mathrm{X} 1$} & \multicolumn{2}{|c|}{$\mathrm{X} 2$} & \multicolumn{2}{|c|}{$\mathrm{X} 3$} \\
\hline & & $t$ & Significane & $r$ & Significance & $r$ & Significance & $r$ & Significanc \\
\hline$a-4$ & 3.86 & 4.869 & 0.000 & 0.419 & 0.026 & 0.472 & 0.011 & - & - \\
\hline$a-5$ & 3.46 & 2.159 & 0.040 & 0.399 & 0.035 & - & - & - & - \\
\hline$a-7$ & 3.60 & 3.525 & 0.001 & - & - & 0.514 & 0.004 & - & - \\
\hline$a-10$ & 3.67 & 3.247 & 0.003 & - & - & 0.375 & 0.041 & - & - \\
\hline$c-1$ & 3.62 & 3.294 & 0.003 & - & - & 0.424 & 0.022 & - & - \\
\hline$c-4$ & 3.75 & 4.965 & 0.000 & - & - & - & - & 0.536 & 0.004 \\
\hline$c-5$ & 3.76 & 5.525 & 0.000 & - & - & - & - & 0.414 & 0.028 \\
\hline$c-6$ & 3.73 & 4.853 & 0.000 & - & - & 0.386 & 0.035 & - & - \\
\hline$c-9$ & 3.87 & 4.709 & 0.000 & 0.523 & 0.003 & - & - & - & - \\
\hline$c-15$ & 4.20 & 6.837 & 0.000 & - & - & - & - & 0.394 & 0.034 \\
\hline ac-3 & 3.87 & 5.517 & 0.000 & - & - & - & - & 0.400 & 0.032 \\
\hline$a c-4$ & 3.93 & 5.413 & 0.000 & - & - & - & - & 0.371 & 0.047 \\
\hline ac-5 & 3.80 & 4.738 & 0.000 & - & - & - & - & 0.576 & 0.001 \\
\hline$a c-6$ & 3.83 & 6.113 & 0.000 & - & - & - & - & 0.471 & 0.010 \\
\hline ac-7 & 3.00 & 0.000 & 1.000 & 0.436 & 0.016 & - & - & - & - \\
\hline ac- 8 & 3.43 & 2.359 & 0.025 & 0.603 & 0.000 & 0.512 & 0.004 & - & - \\
\hline bc- 8 & 3.30 & 1.725 & 0.095 & 0.502 & 0.005 & 0.526 & 0.003 & - & - \\
\hline abc-5 & 4.00 & 6.595 & 0.000 & - & - & 0.367 & 0.046 & - & - \\
\hline abc- 6 & 3.70 & 3.751 & 0.001 & - & - & 0.448 & 0.013 & - & - \\
\hline abc-11 & 4.00 & 6.289 & 0.000 & - & - & - & - & 0.410 & 0.027 \\
\hline
\end{tabular}

Note: a, b, and c in code column refers to client, contractor, and consultant, respectively.

\subsection{Basis for Decision Making (X1)}

Table 6 shows that clients' acceptance of RC practices (a-4) and organizational culture fit to RC practices (a-5) are significantly correlated with the basis for decision making (X1). Ng et al. (2002) 
found that when owners' organizational culture does not fit a RC approach, project partnering would be ineffective. When clients accept the concept of RC and have the ability to implement RC practices, contracting parties can do away with detailed and formal contracts (Palay 1985), and thereafter make decisions that are based more on relational choices.

When consultants make decisions based more on relational mindset (X1), they are likely to commit long term to other contracting parties (c-9). This echoes the finding mentioned previously that consultants play an important role in setting the tone of the relationship in a project. According to the public-client interviewee: "Because of the long-term involvement of consultants in a construction project from inception to project completion, contractors would be more willing to adopt relational transaction if consultants are committed long term to the contractors.”

There is also significant correlation between the basis for decision making (X1) and the ongoing social relationships between clients and consultants (ac-7). This finding suggests that contracting parties are likely to make decisions based on relational transaction when there is a good ongoing social relationship between clients and consultants. The reason may be attributed to the trust and friendship that are present in ongoing relationships, causing contracting parties to be more willing to compromise when problems arise and thus adopting relational transactions (Castro et al. 2009). The implication is that past and current relationships may be taken into account in the selection of consultants.

Table 6 shows that the level of reciprocation and face-saving gestures between clients and consultants (ac-8) and between contractors and consultants (bc-8) is significantly correlated with the basis for decision making (X1) and the focus of organization (X2). According to the interviewees, these factors are cross correlated. When there is a high level of reciprocation or face-saving gesture in place, contracting parties are willing to make relational choices and emphasize the importance of relationships. However, the imposition of reciprocity may deprive other participants of choice because they may choose not to have the reciprocity adjusted in their favour because of the various costs to them in doing so (Macneil 1983).

\subsection{Focus of Organization (X2)}

Table 6 shows the three RC practices that are significantly correlated with the focus of an organization (X2) when they are adopted by clients to a large extent. These are clients' acceptance of RC practices (a-4), clients' flexibility when situations change (a-7), and clients' previous experience in RC approaches (a-10). These findings again reinforce the important role played by public owners in promoting RC practices in the project. Moreover, a construction project is usually characterized by multiple uncertainties, which calls for the flexibility and adaptability of contracting parties in responding to change. Therefore, a-4, a-7, and a-10 are required to persuade other parties to focus more on relationships.

There is significant correlation between the focus of an organization (X2) and the consultants' level of innovation and creativity (c-1) and financial capacity (c-6). This finding suggests that when consultants are innovative and have strong financial capacity, they are likely to focus more on relationships. The contractor interviewee explained that consultants' organizational characteristics such as innovation and financial capacity are related to the consultants' performance. Consultants who perform well are able to differentiate themselves and need not focus on cost minimization or profit maximization. 
There is also a significant correlation between the focus of an organization (X2) and the level of reciprocation and face-saving gestures between clients and consultants (ac-8) and between contractors and consultants (bc-8). This has been discussed in the previous section.

Table 6 shows that the joint coordination and monitoring plans among contracting parties (abc-5) and the clearly defined equitable risk-sharing arrangement among contracting parties (abc-6) are significantly correlated with the focus of an organization (X2). Mohr and Spekman (1994) argued that coordination helps to reflect what each party expects of the other parties in fulfilling a set of tasks. When contracting parties share a strong emphasis on the importance of relationships, they are likely to set up effective joint coordination and monitoring plans. The resultant increase in contact points among the contracting parties will lead to stability in an uncertain environment (Bayramoglu 2001). In addition, when contracting parties focus more on relationships, they are aware of the consequences of the excessive use of exculpatory clauses and ambiguous terms in allocating risks that can lead to a higher possibility of dispute occurrence (Zaghloul and Hartman 2003).

\subsection{Method to Guard against Trouble (X3)}

Table 6 shows that contracting parties are likely to use network and relationships to guard against trouble (X3) when consultants accept and support RC practices (c-4, c-5, and c-15). Because consultants play multifaceted roles in construction projects and are usually involved in the project from inception to project completion, especially in dispute resolution (Ip 2012), their experience in $\mathrm{RC}$ approaches is expected to affect the other parties' choice of resolution should any problem arise.

There is a significant correlation between the method to guard against trouble (X3) and four practices that are adopted in tandem by clients and consultants. These are mutual understanding (ac-3), open and effective communication (ac-4), level of interpersonal relations and cultural harmony at individual level (ac-5), and sharing of project information (ac-6). This finding suggests that contracting parties that rely on trust when handling any challenges are more likely to have mutual understanding, open and effective communication, strong interpersonal relations, and sharing of project information. It is not advisable to rely on formal controls to manage conflicts. Instead, parties should exercise ethics, neutrality, and independence (Van Gramberg 2006). The contractor interviewee shared that this is more so when relationships are much relied on to handle problems because it is considered more flexible.

Two interviewees said that soft methods like renegotiation and mediation instead of hard methods like litigation are increasingly being used to resolve disputes in Australia's construction industry because litigation is costly, time consuming, stressful, and subject to the risk of destroying an organization's reputation in the industry. However, the growing importance of relationships in handling problems does not mean that the clarity of contract conditions such as scope of contract, duties, and responsibilities is any less important. In fact, the higher the level of pre-contract negotiation to clarify contract conditions, the higher the quality of the decision-making process for dispute resolution during the construction phase, and thereafter the lower the intensity of conflict (Aibinu 2009). This is echoed by the significant correlation between the method to guard against trouble (X3) and the clarity of contract conditions (abc-11).

\section{Conclusions}

Using a two-pronged research design, i.e., a questionnaire survey and in-depth interviews, this study investigated whether contract strategies affect project outcomes and interpersonal relations among contracting parties in public construction projects in Australia. The results show that contracting 
parties in public projects adopt a balanced approach that does not lean towards formal controls and rational choice or towards relational contracting. It was also found that cost performance (Y1), client satisfaction (Y4), and relationships among contracting parties (Z1 to Z4) are significantly correlated with contract strategies (X1 to X3). The findings add to the current knowledge base by showing that contract strategies are important and may have an effect on the project performance outcome and relationship quality among contracting parties of public projects. It is therefore important for contracting parties to pay attention to relational contracting when managing public construction projects.

The study also identified RC practices that are significantly correlated with contract strategies (X1 to $\mathrm{X} 3$ ). Among the 20 practices that are found to be significantly correlated with contract strategies, 16 are related to clients and consultants, suggesting that clients and consultants play an important role in setting the tone of the relationship in a project. It is recommended that owners and consultants adopt the practices identified in Table 6 because these are the types of practices that are in place when relational contract strategies on relationships are adopted and these lead to better relationships, better cost performance, and better client satisfaction.

The scope of this study is limited to investigating the associations among RC practices, contract strategies, and outcomes in Sydney, Australia. The interrelation between project outcome variables (Y1-Y4) and relationship variables (Z1-Z4) is outside the scope of this paper but could be a subject of a future research. One limitation faced in this study is the small number of valid responses due to the difficulty in collecting data in Sydney, Australia, by a team based in Singapore. Consequently, advanced analysis techniques like structural equation modelling could not be adopted in this study to explain the complex interrelationship among set of constructs and variables. The next limitation is that contracting parties, especially contractors, may not have complete information of cost and time performance to inform this research. To control the number of outcome variables to reduce complexity in data collection, this study chose client satisfaction instead of stakeholder satisfaction, such as satisfaction experienced by contractors and consultants. In future studies, more sets of data could be collected in order to compare RC practices and contract strategies of the various contracting parties, the satisfaction of different stakeholders, and in different parts of Australia. A case study approach could also be considered, whereby for the same project, data could be collected from different team members so that complete information could be gathered. Relational transaction may be dependent on the capabilities and skills of the individuals. A future study could be conducted to investigate the relative capability of the individuals participating in the contract itself.

\section{Acknowledgments}

The research is made possible by Singapore Ministry of Education's Academic Research Fund Tier 2 funding support (Grant number: MOE2009-T2-2-067) for the project entitled "Boosting public construction project outcomes through relational transactions.” Special gratitude is extended to those industry practitioners and academics who had kindly participated in the surveys and interviews.

\section{References}

Aibinu, A. (2009). "Avoiding and mitigating delay and disruption claims conflict: role of precontract negotiation.” J. Leg. Aff. Dispute Resolut. Eng. Constr., 1(1), 47-58.

Akintoye, A., and Main, J. (2007). "Collaborative relationships in construction: The U.K. contractors’ perception.” Eng. Construct. Architect. Manage., 14(6), 597-617.

American Institute of Architects. (2007). "Integrated project delivery: A guide (version 1)." 〈http://www.aia.org/contractdocs/AIAS077630〉 (Oct. 18, 2012). 
Anvuur, A. M., and Kumaraswamy, M. M. (2007). "Conceptual model of partnering and alliancing.” J. Constr. Eng. Manage., 10.1061/(ASCE)0733-9364(2007)133:3(225), 225-234.

Argyris, C. (1962). Interpersonal competence and organizational effectiveness, Dorsey, Homewood, IL.

Bayliss, R., Cheung, S. O., Suen, H. C. H., and Wong, S. P. (2004). "Effective partnering tools in construction: A case study on MTRC TKE contract 604 in Hong Kong.” Int. J. Proj. Manage., 22(3), 253-263.

Bayramoglu, S. (2001). "Partnering in construction: Improvement through integration and collaboration.” Leader. Manage. Eng., 10.1061/(ASCE)1532-6748(2001)1:3(39), 39-43.

Becker, G. S. (1976). "The economic approach to human behavior.” Economic approach to human behavior, University of Chicago Press, Chicago, 3-14.

Black, C., Akintoye, A., and Fitzgerald, E. (2000). "An analysis of success factors and benefits of partnering in construction.” Int. J. Project Manage., 18(6), 423-434.

Castro, I., Galan, J. L., and Casanueva, C. (2009). “Antecedents of construction projects coalitions: A study of the Spanish construction industry.” Constr. Manage. Econ., 27(9), 809-822.

Chan, A. P. C., Chan, D.W. M., Chiang, Y. H., Tang, B. S., Chan, E. H.W., and Ho, K. S. K. (2004). "Exploring critical success factors for partnering in construction projects.” J. Constr. Eng. Manage., 10.1061/(ASCE)0733-9364(2004)130:2(188), 188-198.

Chan, A. P. C., Chan, D. W. M., Fan, L. C. N., Lam, P. T. I., and Yeung, J. F. Y. (2006). "Partnering for construction excellence-A reality or myth?” Build Environ., 41(12), 1924-1933.

Chan, A. P. C., Chan, D. W. M., and Ho, K. S. K. (2003). "Partnering in construction: Critical study of problems for implementation.” J. Manage. Eng., 10.1061/(ASCE)0742597X(2003)19:3(126), 126-135.

Chen, C. T., and Chen, T. T. (2007). "Critical success factors for construction partnering in Taiwan." Int. J. Proj. Manage., 25(5), 475-484.

Cheng, E.W. L., and Li, H. (2001). "Development of a conceptual model of construction partnering." Eng. Construct. Architect. Manage., 8(4), 292-303.

Cheng, E. W. L., and Li, H. (2002). "Construction partnering process and associated critical success factors: Quantitative investigation.” J. Manage. Eng., 10.1061/(ASCE)0742597X(2002)18:4(194), 194-202.

Cheng, E. W. L., Li, H., and Love, P. E. D. (2000). "Establishment of critical success factors for construction partnering.” J. Manage. Eng., 10.1061/(ASCE)0742-597X(2000)16:2(84), 8492.

Cheung, S. O., Suen, H. C. H., and Cheung, K. K. W. (2003). “An automated partnering monitoring system: Partnering Temperature Index.” Autom. Constr., 12(3), 331-345.

Cheung, S. O., Yiu, K. T. W., and Chim, P. S. (2006). “How relational are construction contracts?” J. Prof. Issues Eng. Educ. Pract., 10.1061/(ASCE)1052-3928(2006)132:1(48), 48-56.

Coase, R. H. (1937). “The nature of the firm.” Economica, 4(16), 386-405.

Crane, T. G., Felder, J. P., Thompson, P. J., Thompson, M. G., and Sanders, S. R. (1999). “Partnering measures.” J. Manage. Eng., 10.1061/(ASCE)0742-597X(1999)15:2(37), 37-42.

Davis, P. R., Love, P. E. D., Miller, G., Furneaux, G., and O’Donnell, A. (2009). "Built environment procurement practice: Impediments to innovation and opportunities for changes.” Rep. for the Built Environment Industry Innovation Council, Australian Government Dept. of Innovation, Industry, Science and Research, Canberra, ACT, Australia.

Dept. of Infrastructure and Transport. (2013). "National alliance contracting policy and guidelines.” 〈http://www.infrastructure.gov.au/infrastructure/nacg/index.aspx〉 (May 30, 2013).

Dept. of Treasury and Finance. (2009). In pursuit of additional value: A benchmarking study into alliancing in the Australian public sector, Melbourne, Australia. 
Doloi, H. (2009). "Relational partnerships: The importance of communication, trust and confidence and joint risk management in achieving project success.” Constr. Manage. Econ., 27(11), 1099-1109.

Dyer, J. H. (1996). "Specialized supplier networks as a source of competitive advantage: Evidence from the auto industry." Strat. Manage. J., 17(4), 271-292.

Eccles, R. (1981). “The quasifirm in the construction industry.” J. Econ. Behav. Org., 2(4), 335-357. Glagola, C. R., and Sheedy, W. M. (2002). "Partnering on defense contracts.” J. Constr. Eng. Manage., 10.1061/(ASCE)0733-9364(2002)128:2(127), 127-138.

Granovetter, M. (1985). “Economic action and social structure: The problem of embeddedness.” Am. J. Sociol., 91(3), 481-510.

Green, D. P., and Shapiro, I. (1996). Pathologies of rational choice theory: A critique of applications in political science, Yale University Press, New Haven, CT.

Gulati, R., and Gargiulo, M. (1999). “Where do inter-organizational networks come from?” Am. J. Sociol., 104(5), 1439-1493.

Guzzo, R. A., and Shea, G. P. (1992). "Group performance and intergroup relations in organizations.” M. D. Dunnette and L. M. Hough, eds., Handbook of industrial and organizational psychology, 2nd Ed., Vol. 3, Consulting Psychological Press, Palo Alto, CA, 269-313.

Halman, J. I. M., and Braks, B. F. M. (1999). “Project alliancing in the offshore industry.” Int. J. Project Manage., 17(2), 71-76.

Hastings, C. (1995). "Building the culture of organizational networking: Managing projects in the new organization.” Int. J. Proj. Manage., 13(4), 259-263.

Hirschman, A. (1977). The passions and the interests, Princeton University Press, Princeton, NJ. Ip, S. (2012). “The role of the consultant in construction.”

〈http://www.cwilson.com/publications/construction/role-of-the-consultant-inconstruction.pdf $\rangle$ (Nov. 8, 2012).

Jones, C., Hesterly, W. S., and Borgatti, S. P. (1997). "A general theory of network governance: Exchange conditions and social mechanisms.” Acad. Manage. Rev., 22(4), 911-945.

Kluenker, C. H. (1996). “The construction manager as project integrator.” J. Manage. Eng, 10.1061/(ASCE)0742-597X(1996)12:2(17), 17-20.

Konchar, M., and Sanvido, V. (1998). “Comparison of U.S. project delivery systems.” J. Constr. Eng. Manage., 10.1061/(ASCE)0733-9364(1998), 124:6(435), 435-444.

Kumaraswamy, M. M., Ling, Y. Y., Rahman, M. M., and Phng, S. T. (2005a). “Constructing relationally integrated teams.” J. Constr. Eng. Manage., 10.1061/(ASCE)07339364(2005)131:10(1076), 1076-1086.

Kumaraswamy, M. M., Rahman, M. M., Ling, Y. Y., and Phng, S. T. (2005b). "Reconstructing cultures for relational contracting.” J. Constr. Eng. Manage., 10.1061/(ASCE)07339364(2005)131:10(1065), 1065-1075.

Larson, E., and Drexler, J. A. (1997). "Barriers to project partnering: Report from the firing line.” Proj. Manage. J., 28(1), 46-52.

Ling, F. Y. Y., Chan, S. L., Chong, E., and Ee, L. P. (2004). "Predicting performance of DB and DBB projects.” J. Constr. Eng. Manage., 10.1061/(ASCE)0733-9364(2004)130:1(75), 75-83.

Ling, F. Y. Y., Rahman, M. M., and Ng, T. L. (2006). "Incorporating contractual incentives to facilitate relational contracting.” J. Prof. Issues Eng. Educ. Pract., 10.1061/(ASCE)10523928(2006)132:1(57), 57-66.

Ling, Y. Y., and Li, S. (2012). "Using social network strategy to manage construction projects in China.” Int. J. Proj. Manage., 30(3), 398-406.

Love, P. E. D., Mistry, D., and Davis, P. R. (2010). "Price competitive alliance projects: Identification of success factors for public clients.” J. Constr. Eng. Manage., 10.1061/(ASCE)CO.1943-7862.0000208, 947-956. 
Machina, M. J. (1987). “Choice under uncertainty: Problems solved and unsolved.” Econ. Perspect., $1(1), 121-154$.

Macneil, I. R. (1983). "Values in contract: Internal and external.” Northwest. Univ. Law Rev., 78(2), 340-347.

Maurer, I., and Ebers, M. (2006). "Dynamics of social capital and their performance implications: Lessons from biotechnology start-ups.” Admin. Sci. Q., 51(2), 262-292.

Mohr, J., and Spekman, R. (1994). "Characteristics of partnering success: Partnering attributes, communication behaviour, and conflict resolution techniques.” Strat. Manage. J., 15(2), 135152.

Ng, S. T., Rose, T. M., Mak, M., and Chen, S. E. (2002). "Problematic issues associated with project partnering - The contractor perspective.” Int. J. Proj. Manage., 20(6), 437-449.

Oliver, C. (1990). "Determinants of inter-organizational relationships: Integration and future directions.” Acad. Manage. Rev., 15(2), 241-265.

Ott, R. L., and Longnecker, M. (2001). An introduction to statistical methods and data analysis, Duxbury Press, Pacific Grove, CA.

Palay, T. (1985). “Avoiding regulatory constraints: Contracting safeguards and the role of informal agreements.” J. Law Econ. Organ., 1(1), 155-175.

Pervan, S. J., Bove, L. L., Johnson, L.W., and Lin, C. H. (2011). "Effect of reciprocity on well-being in interpersonal marketing relationships: An interview study.” Int. J. Manage., 28(1), 185197.

Powell, W. W. (1990). “Neither market nor hierarchy: Network forms of organization.” Res. Organ. Behav., 12, 295-336.

Pryke, S. D. (2004). "Analysing construction project coalitions: Exploring the application of social network analysis.” Constr. Manage. Econ., 22(8), 787-797.

Rahman, M. M., and Kumaraswamy, M. M. (2002a). "Joint risk management through transactionally efficient relational contracting.” Constr. Manage. Econ., 20(1), 45-54.

Rahman, M. M., and Kumaraswamy, M. M. (2002b). "Risk management trends in the construction industry: Moving towards joint risk management.” Eng. Construct. Architect. Manage., 9(2), 131-151.

Rahman, M. M., and Kumaraswamy,M.M. (2004a). "Contracting relationship trends and transitions.” J. Manage. Eng., 10.1061/(ASCE)0742-597X(2004)20:4(147), 147-161.

Rahman, M. M., and Kumaraswamy, M. M. (2004b). "Potential for implementing relational contracting and joint risk management.” J. Manage. Eng., 10.1061/(ASCE)0742597X(2004)20:4(178), 178-189.

Rahman, M. M., and Kumaraswamy, M. M. (2005). "Relational selection for collaborative working arrangements.” J. Constr. Eng. Manage., 10.1061/(ASCE)0733-9364(2005)131:10(1087), 1087-1098.

Rahman, M. M., and Kumaraswamy,M.M. (2008). "Relational contracting and teambuilding: Assessing potential contractual and non-contractual incentives.” J. Manage. Eng., 10.1061/(ASCE)0742-597X(2008)24:1(48), 48-63.

Schwenk, C., and Cosier, R. (1993). "Effects of consensus and devill's advocacy on strategic decision-making.” J. Appl. Soc. Psychol., 23(2), 126-139.

SPSS [Computer software]. IBM.

Tang, W. Z., Duffield, C. F., and Young, D. M. (2006). "Partnering mechanism in construction: An empirical study on the Chinese construction industry.” J. Constr. Eng. Manage., 10.1061/(ASCE)0733-9364(2006)132:3(217), 217-229.

Uzzi, B., and Lancaster, R. (2003). "Relational embeddedness and learning: The case of bank loan managers and their clients.” Manage. Sci., 49(4), 383-399.

Van Gramberg, B. (2006). Managing workplace conflict: Alternative dispute resolution in Australia, Federation Press, Sydney, Australia. 
Walker, D. H. T. (1998). “The contribution of the client representative to the creation and maintenance of good project inter-team relationships.” Eng. Construct. Architect. Manage., 5(1), 51-57.

Williamson, O. E. (1975). Markets and hierarchies: Analysis and antitrust implications, Free Press, New York.

Wong, P. S. P., Cheung, S. O., and Ho, P. K. M. (2005). "Contractor as trust initiator in construction partnering - Prisoner's dilemma perspective.” J. Constr. Eng. Manage., 10.1061/(ASCE)0733-9364(2005)131:10(1045), 1045-1053.

Xu, T., Smith, N. J., and Bower, D. A. (2005). "Forms of collaboration and project delivery in Chinese construction markets: Probable emergence of strategic alliances and design/build.” J. Manage. Eng., 10.1061/(ASCE)0742-597X(2005)21:3(100), 100-109.

Yasamis, F., Arditi, D., and Mohammadi, J. (2002). “Assessing contractor quality performance.” Constr. Manage. Econ., 20(3), 211-223.

Yeung, J. F. Y., Chan, A. P. C., Chan, D. W. M., and Li, L. K. (2007). "Development of a partnering performance index (PPI) for construction projects in Hong Kong: A Delphi study.” Constr. Manage. Econ., 25(12), 1219-1237.

Zaghloul, R., and Hartman, F. (2003). “Construction contracts: The cost of mistrust.” Int. J. Proj. Manage., 21(6), 419-424.

Zaheer, A., and Soda, G. (2009). "Network evolution: The origins of structural holes.” Admin. Sci. Q., 54(1), 1-31. 